\title{
Direct Effects of Progesterone on Rat Islets of Langerhans in vivo and in Tissue Culture
}

\author{
S. L. Howell, Margaret Tyhurst, and Irene C. Green \\ Biochemistry Laboratory, School of Biological Sciences, University of Sussex, Falmer, Brighton, England
}

Summary. Progesterone and oestradiol did not alter rates of insulin secretion from isolated rat islets of Langerhans during a 60 min period of incubation in vitro. However, islets isolated from rats which had been injected daily for 15 days with progesterone $(5 \mathrm{mg})$ and oestradiol $(5 \mu \mathrm{g})$ showed enhanced rates of insulin secretion in response to stimulation by 20 $\mathrm{mmol} / \mathrm{l}$ glucose or 6 and $20 \mathrm{mmol} / 1$ glucose plus $5 \mathrm{mmol} / \mathrm{l}$ theophylline. Islets from rats which had been injected with the slow-releasing depot progesterone derivative, hydroxyprogesterone hexanoate, 3 times in 15 days, also showed enhanced rates of insulin release in the absence of any alteration in adenylate cyclase activity. In neither experiment could increased food intake, blood glucose levels or islet insulin content account for the observed changes. The possibility of a direct effect of progesterone on the secretory process was investigated in islets which had been cultured for $20 \mathrm{~h}$ with progesterone and oestradiol; these islets were then subjected to a variety of stimuli for secretion. They responded significantly more to glucose (6 or 20 $\mathrm{mmol} / \mathrm{l})$ in the presence of theophylline $(5 \mathrm{mmol} / \mathrm{l})$, while their insulin content was not significantly different from control islets cultured for a similar period. Islets cultured for $20 \mathrm{~h}$ in the presence of progesterone and oestradiol did not show any change in their adenylate cyclase activities. Similarly, direct addition of progesterone and oestradiol to islet homogenates did not alter the adenylate cyclase activity during a 30 minute incubation. These results suggest that progesterone and oestradiol affect insulin secretion directly, by a mechanism which does not involve activation of adenylate cyclase.

Key words: Isolated islets, tissue culture, insulin secretion, progesterone, oestradiol, adenylate cyclase.
The existence of mechanisms for the long term regulation of insulin secretion in different physiological states is now well established, and these may be quite independent of the short term, minute-by-minute regulation of secretion. This long term control may be responsible for the reduced insulin response to glucose stimulation in fasting $[8,12]$ and for the enhanced release which is observed after glucose loading [12] or during the later stages of pregnancy [7]. One of the factors which could be involved in mediating this enhanced secretion in mid to late pregnancy is the elevation of progesterone levels which occurs at that time; there have already been reports of indirect effects on islet function of progesterone injected in vivo $[3,9]$.

We report here the effects of treating rats with progesterone and oestradiol in vivo on subsequent patterns of insulin secretion from their isolated islets. In addition, we have investigated the possibility that progesterone and oestradiol may have direct effects on rat pancreatic B-cell metabolism 1 . by testing the direct effects of these hormones on insulin secretion in vitro and 2 . by culturing isolated islets with these steroids for 20 hours before examining their insulin secretory responses to a variety of stimuli, as well as their adenylate cyclase activity.

\section{Methods}

\section{Animals}

Female rats of Sprague-Dawley strain weighing $200-250 \mathrm{~g}$ were used and were allowed free access to food and water throughout. Those animals which received steroid injections were given either $25 \mathrm{mg}$ hydroxyprogesterone hexanoate (Primolut Depot, Schering Chemicals Ltd., Burgess Hill, Sussex) in- 
Table 1. Direct effects of progesterone and oestradiol on insulin secretion from isolated rat islets

Islets isolated from untreated female rats were incubated for 60 $\min$ at $37^{\circ} \mathrm{C}$ in media which contained $20 \mathrm{mmol} / 1$ glucose $+5 \mathrm{mmol} / \mathrm{l}$ theophylline and the additions shown. Each result is the mean \pm SEM of the number of observations shown in parenthesis

\begin{tabular}{lll}
\hline $\begin{array}{l}\text { Progesterone } \\
\mu \mathrm{g} / \mathrm{ml}\end{array}$ & $\begin{array}{l}\text { Oestradiol } \\
\mu \mathrm{g} / \mathrm{ml}\end{array}$ & $\begin{array}{l}\text { Rate of insulin secretion } \\
(\mathrm{ng} / \text { islet } / \mathrm{h})\end{array}$ \\
\hline- & - & $6.76 \pm 0.72(10)$ \\
10 & - & $5.20 \pm 0.76(10)$ \\
- & 1 & $6.64 \pm 0.80(10)$ \\
1 & 0.1 & $5.96 \pm 0.80(10)$ \\
10 & 1 & $4.56 \pm 0.72(9)$ \\
50 & 5 & $580 \pm 0.88(10)$ \\
\hline
\end{tabular}
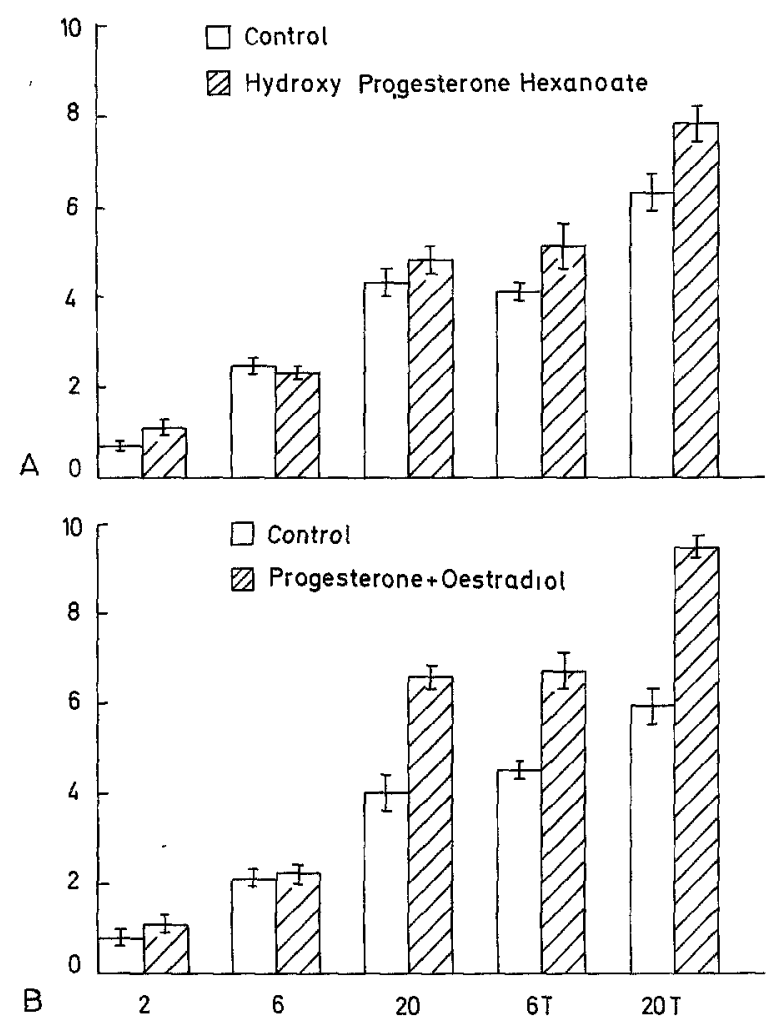

Fig. 1. Insulin secretion from islets isolated from steroid treated rats. A Islets from rats injected with hydroxyprogesterone hexanoate over a 15 day period $\square$; oil injected controls $\square$, mean \pm SEM of 6 observations. B Islets from rats injected daily for 15 days with $5 \mathrm{mg}$ progesterone $+5 \mu \mathrm{g}$ oestradiol hexanoate $\square$; oil injected controls $\square$, mean \pm SEM of 15 observations. Ordinate: ng insulin secreted/islet/hr. Abscissa. Additions to incubation medium: $2,6,20 \mathrm{mmol} / \mathrm{l}$ glucose, $6 \mathrm{mmol} / 1$ glucose + theophylline $(6 \mathrm{~T}), 20 \mathrm{mmol} / 1$ glucose + theophylline $(20 \mathrm{~T})$

tramuscularly every fifth day under ether anaesthesia for a total of 3 injections, or a mixture of $5 \mathrm{mg}$ progesterone and $5 \mu \mathrm{g}$ oestradiol benzoate in sesame oil subcutaneously every day for 15 days. In either case control animals were given identical quantities of the injection vehicle alone.

\section{Isolation and Incubation of Islets}

Islets of Langerhans were isolated by collagenase digestion, by methods which have been described previously [10]. In order to test their insulin secretory responses they were preincubated for $30 \mathrm{~min}$ at $37^{\circ} \mathrm{C}$ in bicarbonate buffered medium [4], containing $5 \mathrm{mmol} / \mathrm{l}$ glucose, either immediately after isolation or after the culture period. Islets were then transferred in groups of three into glass tubes containing $0.6 \mathrm{ml}$ bicarbonate buffered medium, $\mathrm{pH}$ 7.4 , and $1 \mathrm{mg}$ albumin/ml together with 2,6 or 20 $\mathrm{mmol} / \mathrm{l}$ glucose, with or without $5 \mathrm{mmol} / \mathrm{l}$ theophylline, and gassed with $95 \% \mathrm{O}_{2}: 5 \% \mathrm{CO}_{2}$. After 60 min incubation the media were removed and diluted for immunoassay of their insulin content.

\section{Tissue Culture Procedure}

Isolated islets (approx. 60 per dish) were placed in $5 \mathrm{~cm}$ tissue culture dishes containing $5 \mathrm{ml}$ of tissue culture medium 199 (TCM199) with 5\% new born calf serum (Flow Laboratories, Irvine, Scotland), $0.1 \mathrm{mg} / \mathrm{ml}$ streptomycin and 100 units $/ \mathrm{ml}$ penicillin. The test dishes contained progesterone and oestradiol in ethanol at final concentrations of $10 \mu \mathrm{g} / \mathrm{ml}$ and $1 \mu \mathrm{g} / \mathrm{ml}$ respectively. Control dishes were set up to which ethanol alone was added. The dishes were then placed in an incubator at $37^{\circ} \mathrm{C}$ in an atmosphere of $5 \% \mathrm{CO}_{2}: 95 \%$ air for 20 hours. Using this method the islets had not attached to the dishes at the end of the culture period and were repicked into $5 \mathrm{~cm}$ tissue culture dishes containing $5 \mathrm{ml}$ bicarbonate buffered medium together with $5 \mathrm{mmol} / 1 \mathrm{glu}$ cose. The dishes were then replaced in the incubator for $30 \mathrm{~min}$ preincubation. Insulin secretory responses were tested by methods described above.

\section{Other Assay Procedures}

Adenylate cyclase activity was measured by a procedure which has been described in detail elsewhere [11]. $\alpha^{32}$-P ATP was used as substrate and cyclic AMP formed was separated by the use of columns of neutral alumina eluted with $10 \mathrm{mmol} / 1$ tris (hydroxy-methyl)-aminomethane - $\mathrm{HCl}$ (TRIS - $\mathrm{HCl}$ ) $\mathrm{pH} 7.6$ [14].

Proteins were estimated by the method of Lowry [13] using crystalline albumin standards.

Insulin content of incubation media, or of islets after extraction of insulin with ethanol: $\mathrm{HCl}$ : water $(23.5: 0.45: 7.0)$ was determined by immuno-assay, using insulin binding reagent obtained from Wellcome Reagents Ltd., Beckenham, Kent, and insulin iodinated in our laboratory.

Blood glucose concentrations were determined 
Table 2. Insulin secretion from rat islets of Langerhans following 20 hours culture with progesterone and/or oestradiol The mean \pm SEM (60 observations) of the pooled control values obtained in these experiments are shown together with the mean \pm SEM of the 15 test observations in each case. Asterisk indicates significant difference $(p<0.05)$ from control incubated in similar medium after culture in the absence of steroids

\begin{tabular}{|c|c|c|c|c|c|}
\hline \multicolumn{6}{|l|}{ Additions to culture } \\
\hline Progesterone $(\mu \mathrm{g} / \mathrm{ml})$ & 0 & 10 & 0 & 10 & 1 \\
\hline Oestradiol $(\mu \mathrm{g} / \mathrm{mI})$ & 0 & 0 & 1 & 1 & 0.1 \\
\hline $\begin{array}{l}\text { Additions to islet } \\
\text { incubation medium }\end{array}$ & \multicolumn{5}{|c|}{ Insulin secretion (ng/1slet/hour) } \\
\hline $2 \mathrm{mmol} / 1$ glucose & $0.56 \pm 0.04$ & $0.48 \pm 0.10$ & $0.56 \pm 0.06$ & $0.58 \pm 0.12$ & $0.46 \pm 0.08$ \\
\hline $6 \mathrm{mmol} / 1$ glucose & $0.64 \pm 0.06$ & $0.66 \pm 010$ & $0.74 \pm 0.06$ & $1.11 \pm 034$ & $0.72 \pm 0.10$ \\
\hline $20 \mathrm{mmol} / 1$ glucose & $1.62 \pm 0.12$ & $2.02 \pm 0.40$ & $1.48 \pm 028$ & $2.04 \pm 0.28$ & $2.22 \pm 0.54$ \\
\hline $6 \mathrm{mmol} / \mathrm{l}$ glucose & & & & & \\
\hline $\begin{array}{l}+5 \mathrm{mmol} / 1 \text { theophylline } \\
20 \mathrm{mmol} / 1 \text { glucose }\end{array}$ & $1.34 \pm 014$ & $1.54 \pm 0.18$ & $1.38 \pm 0.30$ & $2.28 \pm 0.36^{*}$ & $2.16 \pm 0.40^{*}$ \\
\hline$+5 \mathrm{mmol} / 1$ theophylhne & $4.08 \pm 0.12$ & $5.48 \pm 0.20^{*}$ & $4.34 \pm 0.48$ & $5.64 \pm 0.42 *$ & $4.76 \pm 032 *$ \\
\hline
\end{tabular}

Table 3. Direct effects of progesterone and oestradiol on adenylate cyclase activity in islet homogenates

Results are shown as the percentage of the control basal value which was 1.31 pmoles cAMP formed $/ \mathrm{mg}$ protein $/ 30 \mathrm{~m}$. Each value is mean \pm SEM of 6 observations

\begin{tabular}{|c|c|c|c|}
\hline \multicolumn{3}{|l|}{ Addittons } & \multirow{2}{*}{$\begin{array}{l}\text { Activity } \\
\% \text { contro }\end{array}$} \\
\hline $\begin{array}{l}\text { Progesterone } \\
\mu \mathrm{g} / \mathrm{ml}\end{array}$ & $\begin{array}{l}\text { Oestradiol } \\
\mu \mathrm{g} / \mathrm{ml}\end{array}$ & $\begin{array}{l}\mathrm{NaF} \\
\mathrm{mmol} / \mathrm{l}\end{array}$ & \\
\hline- & - & - & 100 \\
\hline 0.1 & - & - & $91 \pm 7$ \\
\hline 1 & - & - & $114 \pm 8$ \\
\hline 10 & - & - & $121 \pm 9$ \\
\hline 10 & 1 & - & $108 \pm 7$ \\
\hline- & - & 10 & $394 \pm 27$ \\
\hline
\end{tabular}

by a glucose-oxidase method, utilizing commercially available reagents (Boehringer Ltd., Lewes, Sussex, U.K.).

\section{Expression of Results}

Results are expressed throughout as the mean \pm SEM of the number of observations shown in parentheses. Significance of differences between means was' assessed by the use of Student's ' $t$ ' test.

\section{Results}

\section{Direct Effects of Progesterone and Oestradiol on Insulin Secretion}

Direct effects of steroids on islet insulin secretion were tested in one hour incubations in the presence of 2,6 or $20 \mathrm{mmol} / 1$ glucose and also in the presence of 6 or $20 \mathrm{mmol} / \mathrm{l}$ glucose $+5 \mathrm{mmol} / 1$ theophylline (Table 1). In neither case did addition of steroid significantly influence the insulin secretory responses of the islets.

\section{Treatment of Rats with Steroids}

Injection of rats with hydroxyprogesterone hexanoate (Primolut Depot) at a dose of $25 \mathrm{mg}$ every fifth day over 15 days did not result in any significant alteration in their fasting blood glucose concentration or weight gain. Tests of insulin secretion by islets from steroid injected and oil injected control rats showed significantly enhanced secretion by islets from steroid treated rats in response to 6 or 20 mmol/l glucose $(P<0.05)$ provided that theophylline was present in the incubation medium (Fig. 1). This increased responsiveness did not reflect an increase in islet insulin content which was, if anything, lower in the steroid treated animals. Estimation of adenylate cyclase activity in islets isolated from rats after simular treatment showed no difference in basal activity and a significant fall in fluoride stimulated activity (oil injected, basal $3.08 \pm 0.25$ and fluoride stimulated, $7.82 \pm 0.15 \cdot \mathrm{pmol} \mathrm{cAMP} / \mathrm{mg}$ protein $/ 30 \mathrm{~min}$; steroid injected, basal $2.75 \pm 0.15$ and fluoride stimulated $6.57 \pm 0.25$ pmol cAMP formed $/ \mathrm{mg}$ protein $/ 30 \mathrm{~min}$ ).

Daily injection of rats with $5 \mathrm{mg}$ progesterone plus $5 \mu \mathrm{g}$ oestradiol benzoate for 15 days resulted in no significant alteration in fasting blood glucose, although the food intake and weight gain of steroid treated animals were increased by $15 \%$ in comparison to oil injected controls. Insulin secretion by islets from steroid injected animals was again significantly increased in response to $20 \mathrm{mmol} / 1$ glucose alone or 6 or $20 \mathrm{mmol} / 1$ glucose plus theophylline. The absence of any changes in the response to 2 or 
$6 \mathrm{mmol} / 1$ glucose alone apparently excludes the possibility that this change in secretion simply results from higher insulin content of the islets, although a $21 \%$ increase $(p<0.05)$ in insulin content was observed in the present experiments.

\section{Effects of Culture of Islets with Progesterone and Oestradiol on Insulin Secretion}

Responses of islets to $2,6,20 \mathrm{mmol} / 1$ glucose and 6 or $20 \mathrm{mmol} / 1$ glucose $+5 \mathrm{mmol} / 1$ theophylline were tested after culture of the islets for 20 hours in media to which $10 \mu \mathrm{g} / \mathrm{ml}$ progesterone and/or $1 \mu \mathrm{g} / \mathrm{ml}$ oestradiol were added. Steroid was present throughout the 20 hour period of culture but not during the 1 hour incubation period of insulin secretion. Progesterone alone did not significantly alter secretion in response to $20 \mathrm{mmol} / 1$ glucose or $6 \mathrm{mmol} / \mathrm{l}$ glucose + theophylline, but stimulated secretion in response to $20 \mathrm{mmol} / 1$ glucose + theophylline; oestradiol alone had no significant stimulatory effects on secretion (Table 2). Progesterone plus oestradiol stimulated secretion in response to 6 or $20 \mathrm{mmol} / \mathrm{l}$ glucose only in the presence of theophylline (Table 2). Qualitatively similar results were obtained when the concentrations of progesterone and oestradiol in the culture media were reduced to $1 \mu \mathrm{g} / \mathrm{ml}$ and $0.1 \mu \mathrm{g} / \mathrm{ml}$ respectively (Table 2).

There was no significant alteration in insulin or protein contents of the islets after a period of 20 hours culture in the presence of $10 \mu \mathrm{g} / \mathrm{ml}$ progesterone $+1 \mu \mathrm{g} / \mathrm{ml}$ oestradiol. The relevant figures were: insulin content of control islets, $36.5 \pm 0.96$ $\mathrm{ng} /$ islet; steroid treated, $38.4 \mathrm{ng} /$ islet. Protein content of control islets: $0.67 \pm 0.042 \mu \mathrm{g} /$ islet; steroid treated, $0.73 \pm 0.05 \mu \mathrm{g} /$ islet $(20$ observations in each case).

\section{Effects of Progesterone and Oestradiol on Islet Adenylate Cyclase Activity}

Direct effects of progesterone on islet adenylate cyclase activity were tested over a range of concentrations of $0.1-10 \mu \mathrm{g} / \mathrm{ml}$ and at $10 \mu \mathrm{g} / \mathrm{ml}$ in the presence of $1 \mu \mathrm{g} / \mathrm{ml}$ oestradiol (Table 3). Neither hormone had any significant effect on basal or fluoride stimulated cyclase activity in the conditions of these experiments. In a further series of experiments, islets were cultured for 20 hours in the same conditions as before and subsequently homogenized for assay of their adenylate cyclase activity. There was also no effect of culture with the hormone on basal or fluoride-stimulated adenylate cyclase activity measured at the end of the culture period. The relative values were: control cultures - basal
$1.46 \pm 0.09$, fluoride stimulated $6.08 \pm 0.33$, steroid cultures $1.54 \pm 0.11$, fluoride stimulated $6.37 \pm 0.43$ $\mathrm{pmol} \mathrm{cAMP}$ formed $/ \mathrm{mg}$ protein $/ 30 \mathrm{~min}(\mathrm{n}=9)$.

\section{Discussion}

The possible existence of indirect effects of progesterone and oestrogen on pancreatic islet function, which might in particular be important in promoting the development of hyperinsulinism in pregnancy, has been discussed previously. There is no doubt that the administration of progesterone and oestradiol to rats for 21 days can induce islet hypertrophy and increase insulin secretion in a somewhat similar way to that observed in late pregnancy $[3,9]$. We have obtained effects of long term progesterone and oestradiol administration to rats similar to those reported by Costrini and Kalkhoff [3], and also observed lesser changes following injection of the long acting depot progesterone analogue, hydroxyprogesterone hexanoate (Primolut Depot). These changes were not related to changes of blood glucose or food intake. Like Costrini and Kalkhoff [3] we were unable to observe direct effects of progesterone or oestradiol on insulin secretion during short term incubations in vitro, and we have therefore tried to determine whether the effects were mediated directly, but not acutely, on the islets by culturing isolated islets with progesterone and oestradiol for 20 hours and then testing their insulin secretory responses. It was clear from these experiments that progesterone alone or progesterone plus oestradiol were capable of affecting islet function, and that this effect was only manifested during incubations performed with glucose and theophylline. This was very similar to the pattern of responses seen after steroid injection of intact animals (Fig. 1). Thus progesterone can effect pancreatic B cell function directly and although such an effect may take some hours to develop in culture, it does not seem to result merely from an alteration in insulin content of the B cells during the period of culture.

In view of the fact that the effects of steroids after culture were most easily observed in the presence of a phosphodiesterase inhibitor, it seemed worthwhile investigating the possible role of cyclic AMP and in particular of adenylate cyclase in mediating their actions. Even after exposure to the steroid for a period of $20 \mathrm{~h}$, no alteration of islet adenylate cyclase activity could be observed. In addition, there appeared to be no direct effects of either progesterone $(0.1-10 \mu \mathrm{g} / \mathrm{ml})$ or progesterone plus oestradiol on adenylate cyclase activity in islet homogenates; this seems consistent with what is 
known of the mechanism of action of steroid hormones in general [15].

The alterations in the regulation of insulin secretion which occur in late pregnancy in the rat have already been extensively investigated $(5,6)$. In brief, basal rates of secretion in the presence of $2 \mathrm{mmol} / \mathrm{l}$ glucose remained unchanged, but the threshold for stimulation of secretion by glucose was lowered in pregnancy from 5.5 to $4 \mathrm{mmol} / \mathrm{l}$, while the degree of stimulation attained at any stimulatory glucose concentration was increased. Some of the factors which may be involved in eliciting these changes have been identified; islets from 20 -day pregnant rats have increased adenylate cyclase activity and higher cyclic AMP levels than normal, and such an increase in cyclic AMP in normal B cells will elicit an insulin biosynthetic [2] and secretory [7] response to glucose which resembles that seen in pregnancy. This elevation of adenylate cyclase activity results in part from an increased carbohydrate intake, which affects the threshold for glucose stimulation of release [6], and conceivably also from the activating effects of pregnancy hormones. It seems clear from the present study that the elevated concentrations of progesterone and oestrogen which are found towards the end of pregnancy do not affect adenylate cyclase activity directly, but may contribute to the stimulation of secretion provided that the B cell cyclic AMP levels are already raised either physiologically (in pregnancy) or experimentally (with theophylline). Such a mechanism would prevent any gross variation of insulin secretion at various stages of the oestrous cycle when B cell cyclic AMP levels presumably remain at normal levels, although minor variations in glucose tolerance and plasma insulin have been reported between oestrus and dioestrus in the rat [1]. It is equally clear that these steroids do not affect insulin secretion by modulating adenylate cyclase activity in the short or long term, or as a result of a massive increase in B cell insulin content. Investigations of ${ }^{3} \mathrm{H}$ progesterone binding to islet subcellular fractions at present in progress may help to determine the mode of action of steroids in affecting pancreatic B cell activity.

Acknowledgements The technical assistance of Mr David Pernn and financial assistance towards the cost of these experiments from the Medical Research Council, British Diabetic Association and Schering Chemicals Ltd are gratefully acknowledged.

\section{References}

1. Bailey, C. J., Matty, A. J.: Glucose tolerance and plasma insulin of the rat in relation to the oestrous cycle and sex hormones. Horm. Metab. Res. 4, 266-270 (1972)

2. Bone, A.J., Howell, S. L.: Long-term regulation of insulin biosynthesis studied in rat islets of Langerhans: alterations in starvation and pregnancy. Biochem. J. (in press)

3. Costrini, N V., Kalkhoff, R. K.: Relative effects of pregnancy, oestradiol, and progesterone on plasma insulin and pancreatic islet insulin secretion. J. Clin. Invest. 50, 992-999 (1971)

4. Gey, G. O., Gey, M. K.: Maintenance of human normal cells and tumour cells in tissue culture. Am.J Cancer 27, 45-76 (1936)

5. Green, I. C., Taylor, K. W.: Effects of pregnancy in the rat on the size and insulin secretory response of the islets of Langerhans. J. Endocrinol. 54, 317-325 (1972)

6 Green, I. C., Taylor, K.W - Insulin secretory response of isolated islets of Langerhans in pregnant rats: effects of dietary restriction. J. Endocrinol 62, 137-143 (1974)

7 Green, I. C., Howell, S.L., Montague, W., Taylor, K. W.: Regulation of insulin release from isolated rat islets of Langerhans in pregnancy. Biochem. J. 134, 481-487 (1973)

8. Grey, N. J , Goldring, S., Kipnis, D.M.. Effect of fasting, diet and actinomycin $\mathrm{D}$ on insulin secretion in the rat. $\mathbf{J}$. Clin. Invest. 49, 881-889 (1970)

9. Hager, D., Georg, R.H., Leitner, J. W., Beck, P.: Insulin secretion and content in isolated rat pancreatic islets following treatment with gestational hormones. Endocrinology 91, 977-981 (1972)

10. Howell, S. L., Taylor, K. W.: Effects of glucose concentration on incorporation of $\left({ }^{3} \mathrm{H}\right)$-leucine into insulin in isolated rabbit islets of Langerhans. Biochim. Biophys. Acta 130, 519-521 (1966)

11 Howell, S. L., Montague, W.. Adenylate cyclase activity in solated rat islets of Langerhans; effects of insulin secretagogues. Biochim. Biophys. Acta 320, 44-52 (1973)

12. Howell, S. L., Green, I. C., Montague, W.: Long term effects of glucose on adenylate cyclase activity in rat isłets of Langerhans. Blochem. J 136, 343-349 (1973)

13. Lowry, O.H., Rosebrough, N J., Farr, A.L., Randall, R J.: Protem measurement with the Folin-phenol reagent. J Biol. Chem. 193, 265-275 (1951)

14. Ramachandran, J : A new simple method for separation of cyclic AMP from other nucleotides and its use in the assay of adenyl cyclase. Anal. B1ochem 43, 227-230 (1972)

15 Schulster, D. S., Burstein, S., Cooke, B A.. In. Molecular endocrinology of the steroid hormones, p 245 London. J Wiley \& Sons 1976

Received: March 31, 1977, and in revised form $\cdot$ June 8, 1977

Dr. S. L. Howell

School of Biological Sciences

University of Sussex

Falmer

Brighton BN 19 QG

England 